\title{
Geomorphological mapping and geophysical profiling for the evaluation of natural hazards in an alpine catchment
}

\author{
A. C. Seijmonsbergen ${ }^{1}$ and L. W. S. de Graaff ${ }^{2}$ \\ ${ }^{1}$ Institute of Biodiversity and Ecosystem Dynamics (IBED), University of Amsterdam, Nieuwe Achtergracht 166, 1018WV \\ Amsterdam, The Netherlands \\ ${ }^{2}$ Research Foundation for Alpine and Subalpine Environments, Stern 6, 1721 DS, Broek op Langedijk, The Netherlands
}

Received: 18 October 2005 - Revised: 11 January 2006 - Accepted: 16 January 2006 - Published: 15 March 2006

\begin{abstract}
Liechtenstein has faced an increasing number of natural hazards over recent decades: debris flows, slides, snow avalanches and floods repeatedly endanger the local infrastructure. Geomorphological field mapping and geoelectrical profiling was used to assess hazards near Malbun, a village potentially endangered by landslides, and especially debris flows. The area is located on the tectonic contacts of four different nappe slices. The bedrock consists of anhydrite and gypsum, dolomite, shale, marl, and limestone. The spatial distribution and occurrence of debris flows and slides is evaluated through a combination of geomorphological expert knowledge, and detailed visualization in a geographical information system. In a geo-database a symbol-based 1:3000 scale geomorphological map has been digitized and rectified into polygons. The polygons include information on the main geomorphological environment, the Quaternary material distribution and of geomorphological processes, which are stored in attribute tables. The spatial distribution of these attributes is then combined with geophysical information and displacement rates interpolated from benchmark measurements. On one of the landslides two geo-electrical profiles show that the distance to a potential failure plane varies between $10-20 \mathrm{~m}$ and that the topography of the failure plane is influenced by subterranean gypsum karst features. The displacement measurements show that this landslide actively disintegrates into minor slides and is not, therefore, a risk to the village of Malbun. The hazard zonation indicates that debris flows can pose a risk if no countermeasures are taken. Gypsum karst may locally accelerate the landslide activity. In contrast, the impact of debris flows is diminished because collapse dolines may act as sediment traps for the debris flow materials. This research illustrates how geomorphological expert knowledge can be integrated in a GIS for the evaluation of natural hazards on a detailed scale.
\end{abstract}

Correspondence to: A. C. Seijmonsbergen

(a.c.seijmonsbergen@uva.nl)

\section{Introduction}

Population growth, expanding tourism and recent land use changes are some of the reasons that many mountain regions are confronted with an increasing number of natural hazards and damage to infrastructure (Rickli and Banzer, 1996). Malbun is a village located in the south-eastern part of Liechtenstein, a small alpine country between Switzerland and Austria (Fig. 1). Historical records reflect that debris flows reached some houses over the last 100 years (Wenzel, 1985). Over the last decade there is a growing concern that debris flows, slides and avalanches might damage the infrastructure of Malbun village. Therefore, a joint research project of the Institute for Biodiversity and Ecosystem Dynamics (IBED) and the "Landesamt für Wald, Natur und Landschaft" (Forest, Nature and Landscape Department) in Vaduz, Liechtenstein (de Graaff and Seijmonsbergen, 2000 ${ }^{1}$ ) was started. The major goal was mapping and evaluation of a gypsum underlain landslide, and especially the debris flows that occurred in the Schlucher catchment, which is located directly east of Malbun (Fig. 1, photo). Many types of landslides occur in the 51 ha large catchment of the Schlucher. Rock fall is active along the upper steep dolomite cliffs and local limestone exposures along the southern slopes. Debris flows can be generated from the available talus and weathering material at the foot of these cliffs. The transition of steeper to gentle terrain is characterized by numerous smaller and larger slides, both rotational and planar. The middle part of the catchment is taken in by a gypsum underlain landslide. Benchmarks were installed on and around this landslide, and have been measured on a yearly basis. The widespread occurrence of gypsum in both the upper and middle reaches

\footnotetext{
${ }^{1}$ de Graaff, L. W. S. and Seijmonsbergen, A. C.: Erdwissentschaftliche Untersuchungen im Schlucher (Malbun, Fürstentum Liechtenstein), Report to "Landesamt fur Wald, Natur und Landschaft, Liechtenstein", Unpublished report, University of Amsterdam, 2000.
} 


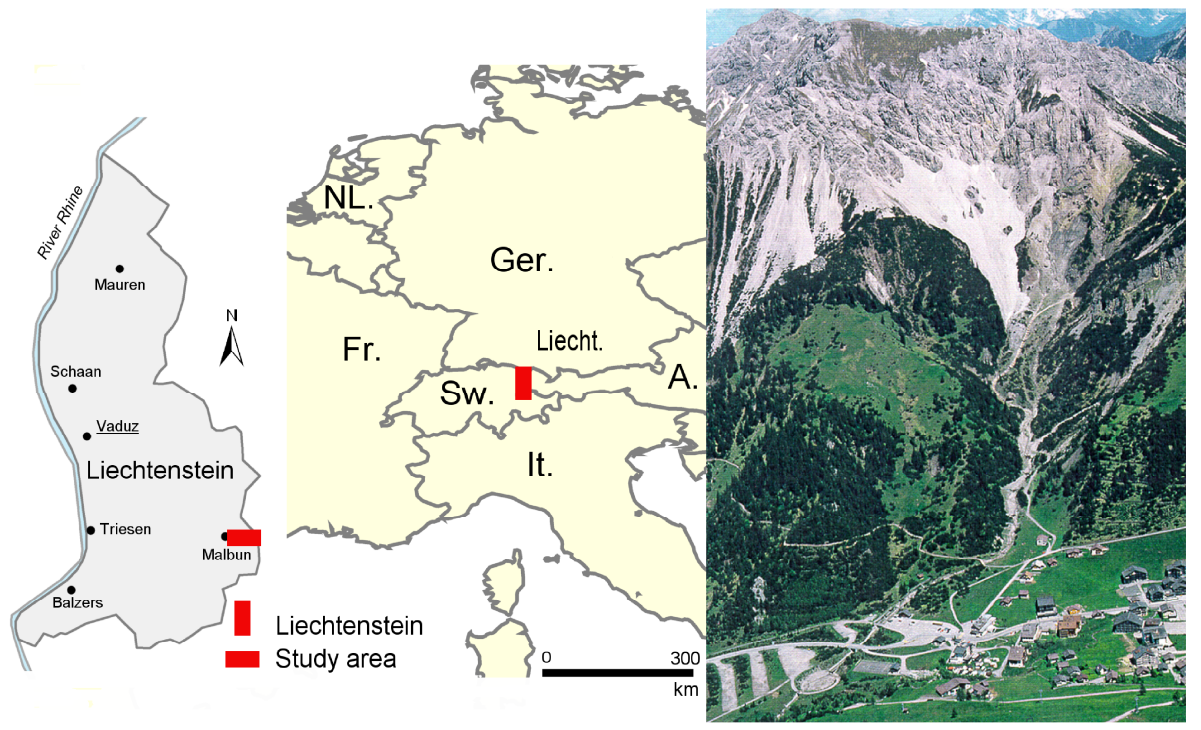

Fig. 1. Location of the study area. The photo shows the small "Schlucher" catchment.

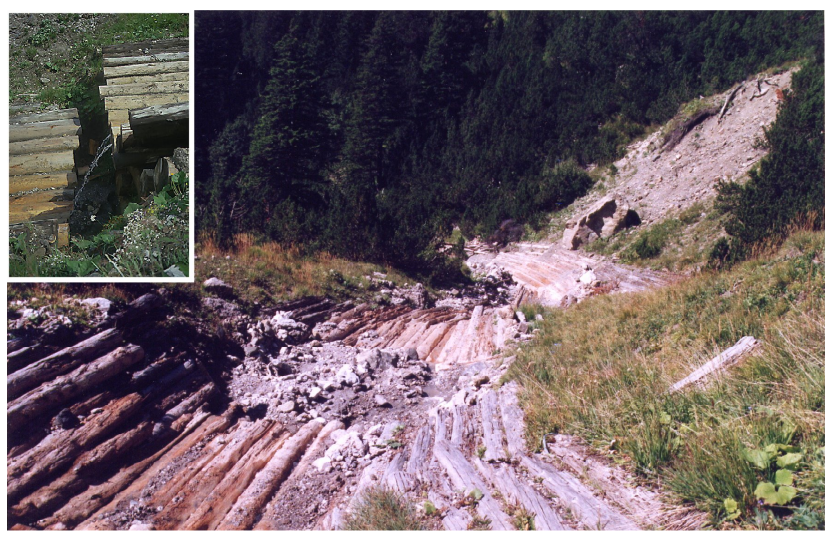

Fig. 2. The wooden drainage system is disrupted by the eroding power of debris flows, by small slides from the adjacent slopes (top right) and by differential movements within the landslide (detail top left), which leads to increased displacements rates.

of the area is evidenced by the presence of numerous solution features, such as dolines and collapse depressions. The distribution of all these features has been documented in the geomorphological map (Fig. 3). "Movement of the land" is known to occur for a long time in the Schlucher catchment. In Table 1 a summary of the major damaging events and measurements taken in relation to the historical torrent control program is presented (after Wenzel, 1985). Since the early 1980s a new torrent control program was started. In 1983 a new series of concrete check dams and a system of artificial wooden channels were built to improve runoff and to lower the local groundwater table, with the objective of reducing the landslide displacement rates. After approximately fifteen years the wooden system was damaged, due to differential displacements within the landslide and the erosive forces of debris flows (Fig. 2). The resulting infiltration increased the displacement rates. It was noticed by Wenzel (1985) that the landslide could pose a serious threat to Malbun; in the event of a sudden failure over $500000 \mathrm{~m}^{3}$ of material could be released. We therefore decided to evaluate the landslides and especially the displacement pattern and depth of the landslide in the central part of the catchment (see Fig. 3). The objectives of the study were: 1 . to prepare a detailed 1:3000 geomorphological map that shows the spatial distribution of all landforms and processes; 2 . to carry out a geophysical analysis over the gypsum underlain landslide, and 3. to present a GIS-supported hazard zonation of debris flows.

Hazard zonation is the division of the land surface into areas and the ranking of these areas according to actual or potential hazards posed by landslides and other mass movements (Varnes, 1984). The delineation of these zones is of crucial importance for quantifying and reducing the risks associated with geomorphological hazards. The method followed here is an adaptation of direct mapping methods described by Soeters and Van Westen (1996) and Van Westen et al. (1997). It comprises a detailed geomorphological map, prepared using the legend developed by de Graaff et al. (1987) and Seijmonsbergen (1992) for mountainous areas. For the purpose of GIS-data handling and visualizing of thematic maps a geo-database was designed in ArcGIS which integrates geological information, geomorphological data, elevation data, displacement measurements and orthorectified air-photos. We used the concept of "Terrain Mapping Units" (TMU), which was already applied in traditional and in GIS-based mapping (Dorren, 2002; Garcia-Mélendez, 1998; Iqballudin, 1999; Meyerink, 1988; Seijmonsbergen, 1992; Suryana, 1996). Many other "terrain unit" approaches 
Table 1. Historical torrent control data in the Schlucher catchment (after Wenzel, 1985).

\begin{tabular}{|c|c|c|c|}
\hline Year(s) & Reported damage & Measures taken & Costs \\
\hline $1700-1900$ & $\begin{array}{l}\text { "major" changes in slope steepness caused by } \\
\text { "movement of the land", loss of land }\end{array}$ & Not mentioned & Not known \\
\hline $1921-1936$ & Vertical stream erosion, enlargement of steep slopes & Erection of dams in lower section & 2900 SFr. \\
\hline 1937-1946 & $\begin{array}{l}\text { Erosion of dam foundation } \\
\text { Severe debris flows }\end{array}$ & Repair activities & $14300 \mathrm{Sfr}$. \\
\hline $1966 / 1968$ & Erosion of dam foundation & 8 new dams & 183000 SFr. \\
\hline $1973-1975$ & None, but: Awareness of flooding, debris flow risk & Raising of lateral dam along channel & 156000 SFr. \\
\hline End of $1970 \mathrm{~s}$ & $\begin{array}{l}\text { Dams from 1960s damaged because of } \\
\text { gypsum rich water dissolved concrete. }\end{array}$ & $\begin{array}{l}\text { Renewal of stream channel, } \\
\text { construction of a sediment basin }\end{array}$ & $>500000 \mathrm{SFr}$ \\
\hline 1980-1984 & $\begin{array}{l}\text { One dam from 1930s destroyed } \\
\text { Increase in landslide activity } 1983\end{array}$ & $\begin{array}{l}\text { Repair old dams, installing wooden } \\
\text { channels, reduction of } \\
\text { infiltration, lowering of channel bed }\end{array}$ & Many millions SFr. \\
\hline
\end{tabular}

have been proposed - e.g. the Desertification Response Units (Imeson and Cammeraat, 1999). All these approaches unify the concept of dividing the landscape into areas of comparable characteristics. The digitized 1:3000 scale geomorphological map is the main document for the hazard zonation. The difference between this GIS-supported hazard zonation and other GIS-based studies is the detailed scale, which allows the fine patterns within the landslides to be linked to the displacement patterns in the benchmark measurements. Recently, various statistical techniques have been used in regional hazard studies (Fernandez et al., 2003; Ercanoglu et al., 2003; Santacana et al., 2003), in which local geomorphological expert knowledge input was only implicitly included. Guzzetti et al. (1999) provide an overview of methods used in hazard studies. Another trend is to use Information Systems for the assessment and management of natural hazards (e.g. Dai et al., 2002; Guzzetti and Tonelli, 2003; Gaspar et al., 2004).

\section{Geology and geomorphology}

\subsection{Introduction}

The success of a qualitative hazard zonation in alpine areas is related to the detail and the reliability of the produced maps. In Liechtenstein, detailed geological maps are available (Allemann, 1985), but geomorphological maps are not. The required detail for hazard zonation, the spatial surface distribution of the materials and the variation in geomorphological processes were the reasons to construct a geomorphological map that reflects not only individual landforms, but also shows relations between such landforms, in time and in space. Therefore, we have chosen a 1:3000 map scale, so that the displacement measurements and the results of geoelectrical profiles could be easily matched with patterns of landslides. For a better understanding of these relations, a brief description of the geological situation and the geomorphological landscape development is required.

\subsection{Geological setting}

The Malbun area is located in the northern calcareous Alps and belongs to the Austro-alpine nappe complex of the Eastern Alps (Ring et al., 1988). Table 2 summarizes the main tectonic units, their lithological formations and main bedrock types important for this research. Here, the "Lechtal" nappe is fragmented into three slices; the "Augstenberg" slice, the "Ochsenkopf-Fundlkopf" slice and the "HeubuhlSchonberg" slice (Allemann, 1985). In between these units the Penninic Arosa-Zone is discontinuously exposed. Tectonic shear zones mainly developed in the less resistant formations (Raibler and Arosa Formations) are more prone to mass movement processes. The Raibler Formation records shallow marine conditions, in which large amounts of anhydrite and gypsum were deposited. These evaporitic rocks alternate with silicate, silt and mud layers (Helmcke, 1974). The overlying formation is the resistant "Hauptdolomit" Formation and represents tidal flat deposits (Oberhauser, 1998). The Arosa Formations form a tectonic mélange of various rock types, ranging from breccia to sandstone and marl (Kobel, 1969). The rocks of the Arosa Formations are often intermixed with materials coming from the Raibler Formation. The Arlberg Formation is composed by a sequence of alternating light to dark grey, thickly layered and highly fractured limestone and thin marl beds. The Partnach Formation is characterized by thinly layered clay- and siltstone. The Muschelkalk Formation is a resistant, dark grey, layered limestone and typically has open fractures.

\subsection{Geomorphological landscape development}

The actual landforms in the study area are the result of glacial, late-glacial and in particular postglacial processes. 
Table 2. Geological data of the study area (after Kobel, 1969, and Alleman, 1985).

\begin{tabular}{|c|c|c|c|c|}
\hline Period & Age & Formation & Dominant lithology & Tectonic unit \\
\hline $\begin{array}{l}\text { Jurassic to } \\
\text { Cretaceous }\end{array}$ & $\begin{array}{l}\text { Dogger to } \\
\text { Turonian }\end{array}$ & Aorsa Zone & $\begin{array}{l}\text { marl, sandstone, } \\
\text { conglomerate }\end{array}$ & $\begin{array}{l}\text { Arosa nappe } \\
\text { Exposed at the base of the } \\
\text { Lechtal nappe slices - served } \\
\text { as décollement zone }\end{array}$ \\
\hline \multirow[t]{5}{*}{ Triassic } & Norian & Hauptdolomit Formation & dolomite & $\begin{array}{l}\text { Lechtal nappe } \\
\text { three nappe slices: Augsten- } \\
\text { berg, Ochsenkopf-Fundlkopf } \\
\text { Heubuhl-Schonberg slice }\end{array}$ \\
\hline & Carnian & Raibler Formation & $\begin{array}{l}\text { anhydrite, gypsum, } \\
\text { rauhwacke, breccia, } \\
\text { marl, sandstone }\end{array}$ & \\
\hline & Ladinian & Arlberg Schichten & $\begin{array}{l}\text { limestone, intercala- } \\
\text { tion of marl }\end{array}$ & \\
\hline & & Partnach Schichten & limestone and marl & \\
\hline & Anisian & Muschelkalk & limestone & \\
\hline
\end{tabular}

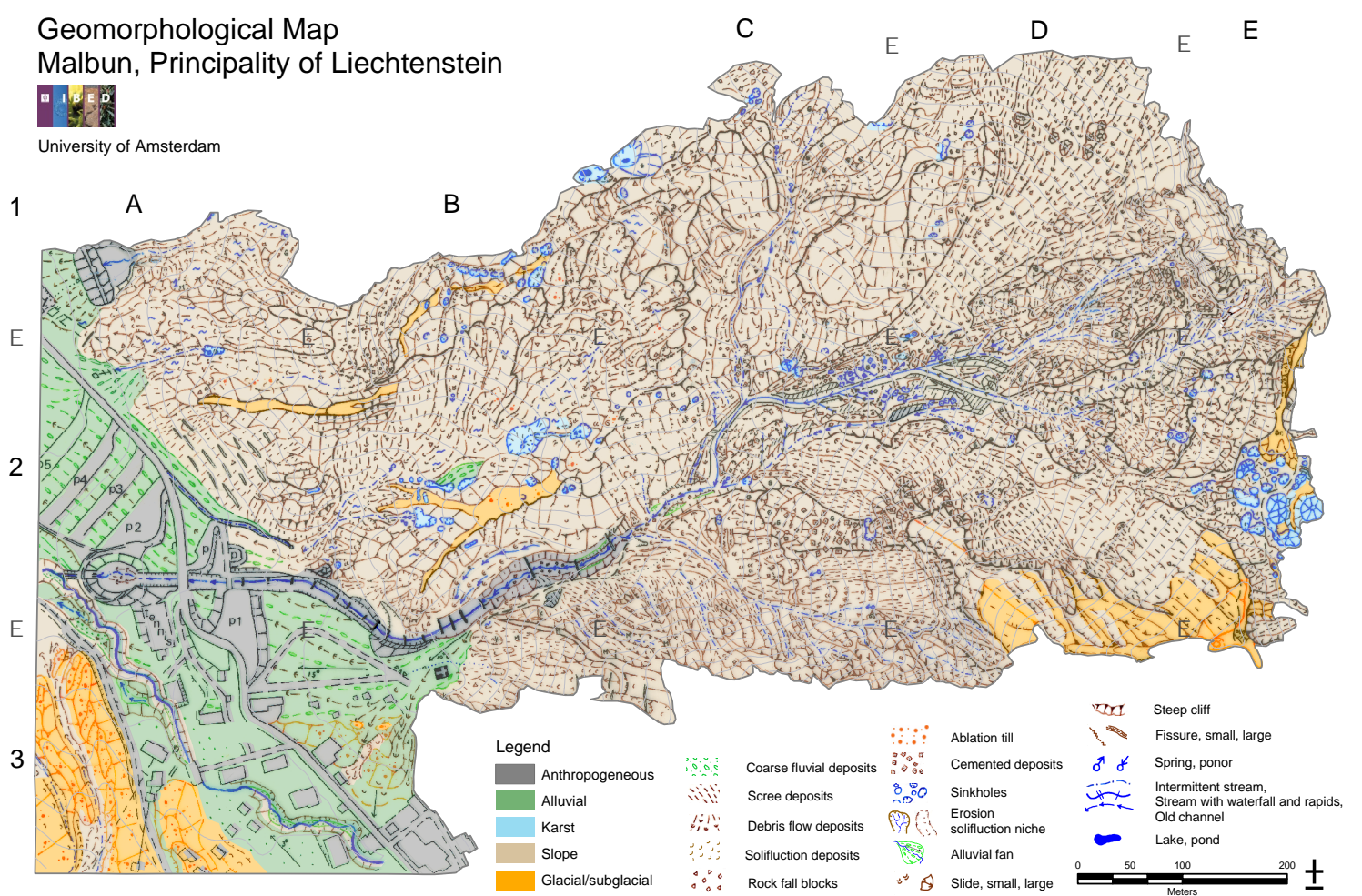

Fig. 3. Geomorphological map Malbun, Principality of Liechtenstein.

The geomorphological map of the Schlucher catchment (Fig. 3) shows landforms and processes at the 1:3000 scale. The legend is a modified version of the legend developed for alpine areas by de Graaff et al. (1987) and Seijmonsbergen (1992). The scale of the map ensures that most geomorphological features are represented without generalizations. For ease of reference the map is divided into squares A1-E3 with A1 in the NW and E3 in the SE corner (Fig. 3).
The area is dominated by both surface and deep seated mass movement. Therefore, few relicts of glacial landforms and deposits have been preserved. Only local ridges between some sub-catchments (e.g. in square B2) and a series of moraine ridges in $\mathrm{A} 3$ have been preserved. These ridges document a late-glacial blockage of the Schlucher catchment by the larger Malbun glacier. This blockage caused a local rise of the erosion base. This resulted in the accumulation of 
Table 3. The four attributes in the geomorphological table: geomorphological environment, Quaternary deposits, process type and lithology. This table only contains those attributes that are representative for this area.

\begin{tabular}{llll}
\hline $\begin{array}{l}\text { Geomorphological } \\
\text { environment }\end{array}$ & Quaternary deposits & Process type & Lithology \\
\hline Anthropogeneous & Anthropogeneous materials & Anthropogeneous & not exposed \\
Alluvial & Residual soils & Fluvial action & Muschelkalk Formation \\
Karst & Alluvial fan deposits & Rock creep/disintegration/fissuring & Partnach Formation \\
Slope & Valley floor deposits & Rock- and screefall & Arlberg Formation \\
Glacial, including subglacial & Fine scree, limestone & Solifluction & Raibler Formation \\
& Fine scree, dolomite & Debris flow & (sulphates) \\
& Fine scree, other & Sliding/slumping & (other) \\
& Rock fall blocks, limestone & Karst (chemical erosion) & Hauptdolomit \\
& Rock fall blocks, dolomite & Glacial action & Formation \\
& Rock fall blocks, other & & \\
& Solifluction material/colluvium & & \\
& Debris flow material, dolomite & & \\
& Debris flow material, limestone & & \\
& Debris flow material, other & & \\
& Ablation till & & \\
& water & &
\end{tabular}

low angle debris flow materials against the former ice margin. The sediments have partly survived the postglacial erosion and are no longer areas of active debris flow.

The presence of gypsum and anhydrite leads to collapse karst and naked karst landforms. In a runoff and debris flow channel in square $\mathrm{C} 2$ a collapse depression was formed in 1999 (Fig. 3). These collapse depressions can substantially decrease the impact of debris flows, because they serve as debris traps and, therefore, reduce mass and momentum. An example of naked karst in sub-horizontal terrain is shown e.g. at the local water divide in square B1. Some of these sinkholes are elongated and aligned, and this suggests that they are related to faults or thrust zones in the Raibler Formation.

In the central part of the Schlucher catchment a landslide underlain by gypsum is present (Wenzel, 1985). The outline of the central landslide is shown in Fig. 6. The back scar is located between 1850 and $1920 \mathrm{~m}$, the side scars reach downslope to approximately $1800 \mathrm{~m}$ and expose heavily tectonized gypsum and anhydrite layers (Fig. 4). The lower end of the landslide is now situated at $1700 \mathrm{~m}$ altitude, which suggests a minimum displacement of $150 \mathrm{~m}$. Rapid mass movements occur along the steep upper surrounding cliffs. Rock- and scree fall produces vast amounts of scree slopes which serve as source areas for debris flows, e.g. in square D1 (Fig. 3).

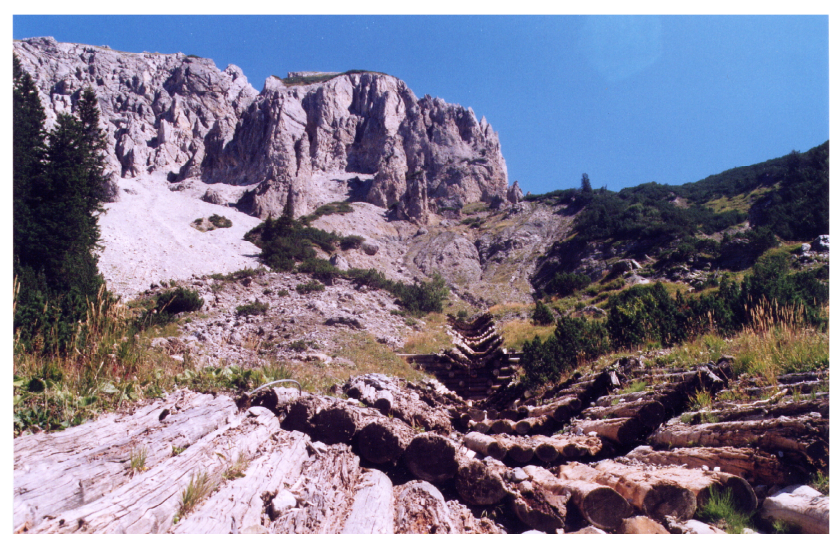

Fig. 4. Upslope view with the steep Hauptdolomite cliffs and associated scree slopes in the upper left part. The central part of the photo shows the major scarp of the gypsum underlain landslide. In the foreground the eroded drainage system is shown.

\section{Mapping and measurement methods}

\subsection{Mapping}

The traditional symbol-based geomorphological map was prepared in the field using a topographical contour line map (original scale 1:10000) and stereo infrared imagery (mean scale approximately 1:12000) for both location and interpretation purposes. The resulting 1:3000 geomorphological map was scanned and georeferenced and used in all further GIS analyses and visualizations as a background image. In this 


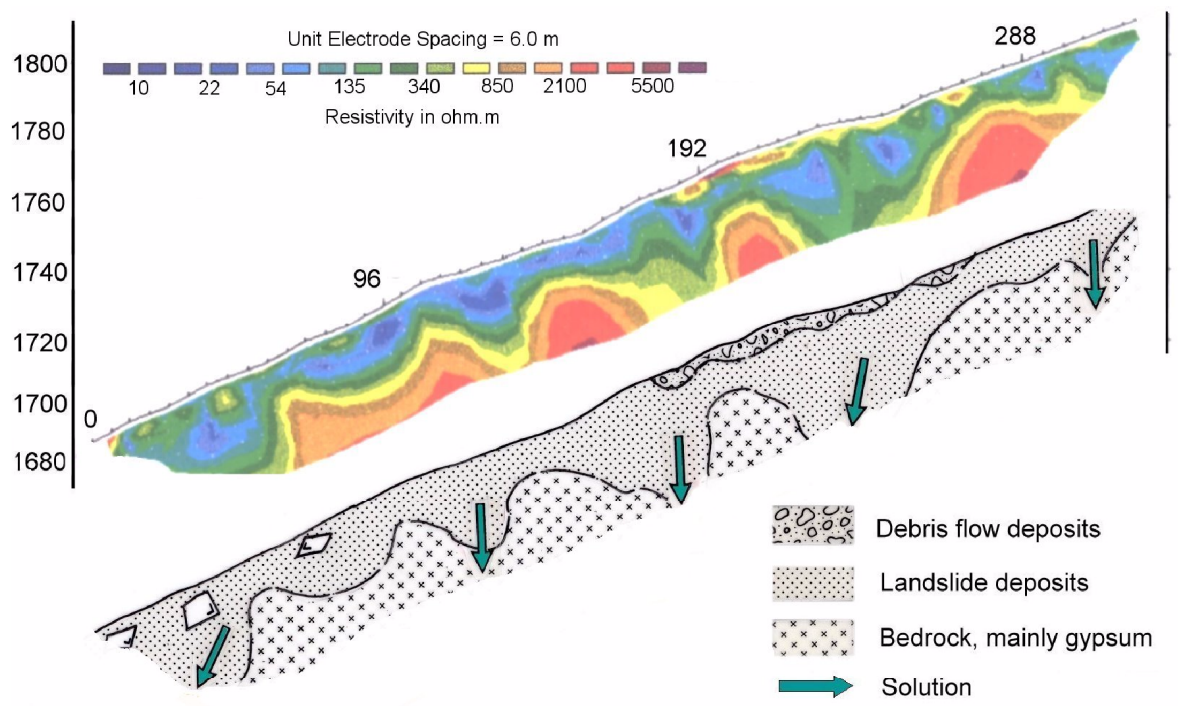

Fig. 5. Top: subsurface resistivity profile along the central landslide, for profile location see Fig. 7. The lower part shows a three layer geological interpretation of the resistivity profile.

way, the original landscape boundaries, the distribution of materials, processes and interpretation of genesis can still be consulted. The original symbol-based legend was translated into a vector-based GIS legend. The geomorphological terrain mapping units were digitized on screen by the geomorphological expert, and contain information on process, form and materials. For each polygon the attribute table was filled in. Table 3 lists the information on the geomorphological environment, the quaternary deposits, the process type and the lithology. These attributes can be displayed as thematic maps by using transparent legend colours over the original geomorphological map (Figs. 3 and 6).

The hazard zonation map (Fig. 7) is prepared by selecting those areas from the attribute table that are related to the actual process of debris flows and to those areas underlain by inactive debris flow source materials and deposits. In the field we noticed from local exposures that areas underlain by thick solifluction deposits often contain debris flow deposits. For this reason, areas underlain by solifluction deposits were also selected to define the hazard zone. The degree of hazard used is: low, medium or high. High activity refers to areas with current debris flow activity. These areas can easily be distinguished from the ortho-photo because of their high reflectance, absence of vegetation and the non-weathered debris fragments in the field. Medium activity refers to areas showing distinct vegetation growth (grass, low shrubs), and a slightly raised position in the terrain. Low activity was assigned to all other debris flow deposits and solifluction areas. The latter may act as debris generating areas in the Schlucher catchment. In practice, minor manual additions and/or changes of the hazard zonation were made by the expert during the process of preparation of the hazard zonation map.

\subsection{Geophysical profiling and displacement measurements}

The gypsum underlain landslide in the central part of the catchment was investigated in more detail. In 1983 a system of benchmarks was installed on and around the lower part of the central landslide. Since 1985 the horizontal and vertical displacements are recorded by the "Landesamt Für Wald, Natur und Landschaft in Vaduz (de Graaff and Seijmonsbergen, $2000^{1}$ ). In total 26 benchmarks were digitised and their yearly movement rates were recorded in point attribute tables. Fifteen benchmarks are located on the landslide of interest. In Fig. 6 the interpolated total horizontal displacement is shown. In ArcGIS the outline of the central landslide acted as a boundary mask for inverse distance weighting interpolation within the landslide. Two geo-electrical profiles with a length of respectively $330 \mathrm{~m}$ and $246 \mathrm{~m}$ were constructed over the crown of the landslide using a Sting-Swift earth resistivity meter. The aim of the geophysical profiling was to determine the depth of failure and to better understand the nature of the displacements. The distance between each of the 28 electrodes was $6 \mathrm{~m}$, which allowed a penetration depth of $20-30 \mathrm{~m}$. The resistivity values depend on the conductivity characteristics of the subsurface materials. Non-weathered bedrock has a relatively high resistivity, whereas disrupted anhydrite and gypsum rocks appeared to have low resistivity.

\section{Results and interpretations}

The location and relations between processes, material and form are derived from the geomorphological map (Fig. 3). The source area of the debris flow deposits are shown in the process attribute map (Fig. 6), which suggests that debris 


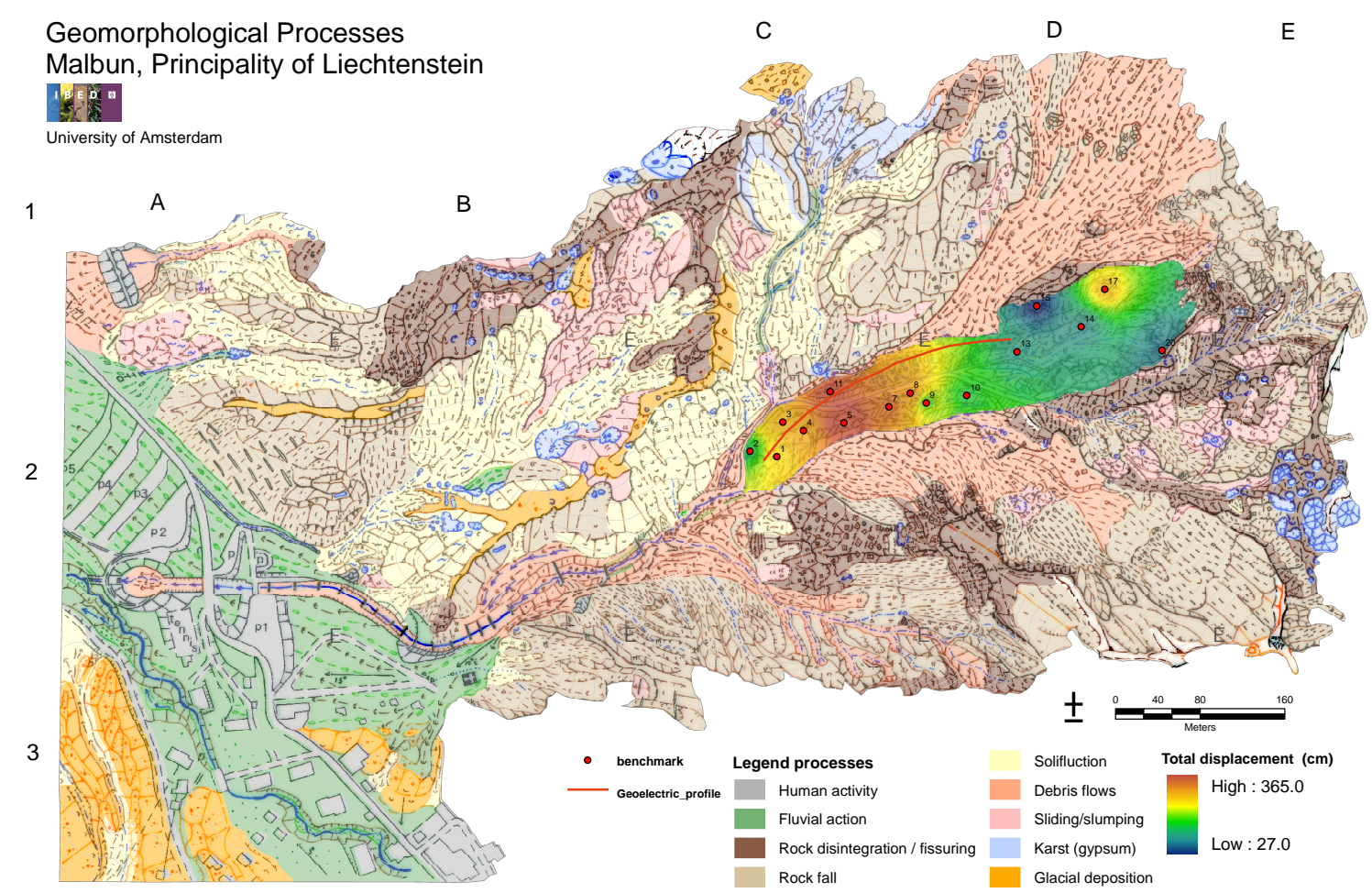

Fig. 6. Geomorphological processes Malbun, Principality of Liechtenstein.

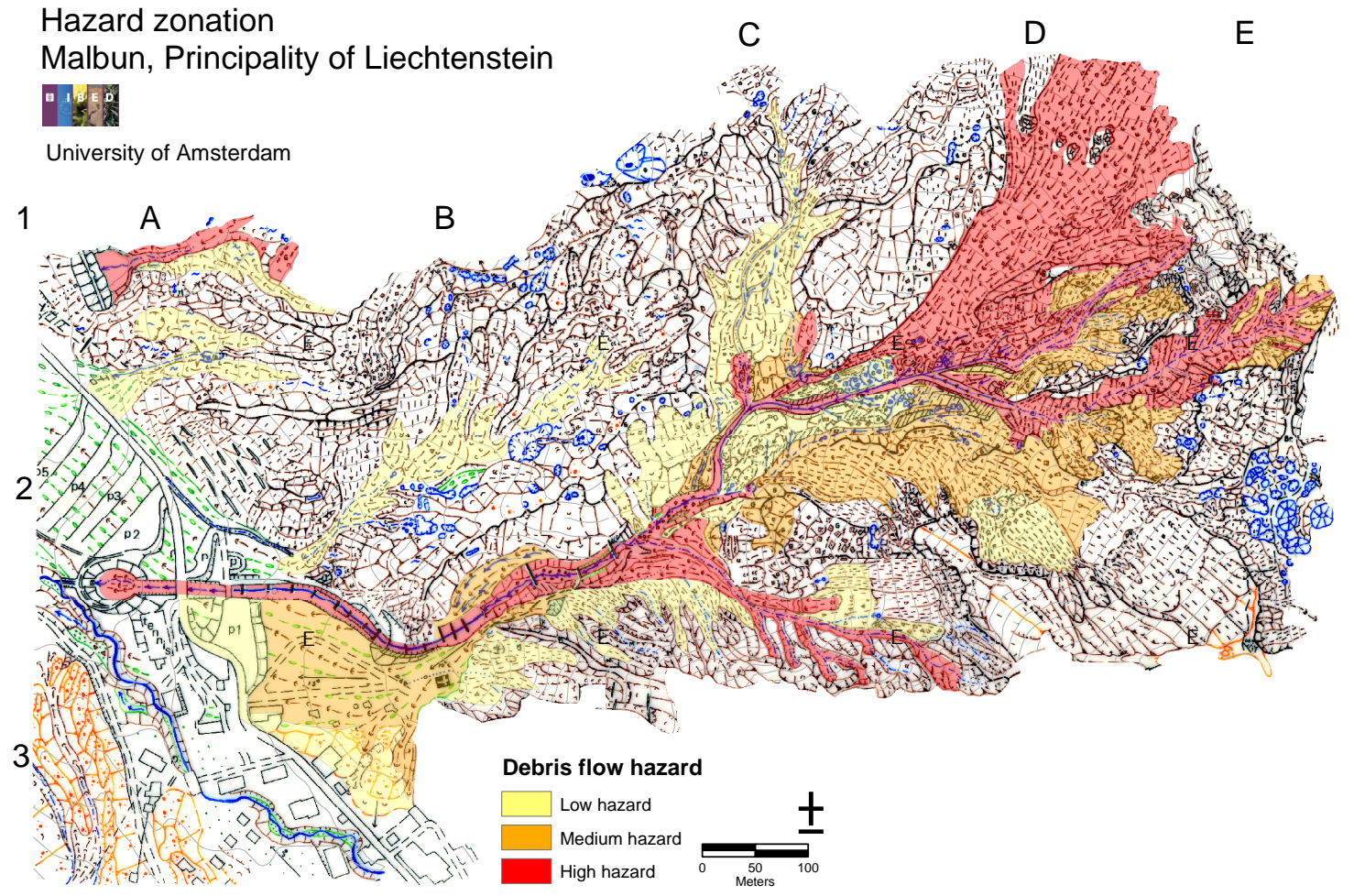

Fig. 7. Hazard zonation Malbun, Principality of Liechtenstein. 
flows may still reach parts of Malbun village. The occurrence of surface collapse dolines, in active debris flow tracks, is evidence that these features may hamper sediment transport by debris flows. The two geo-electrical profiles showed similar resistivity patterns; hence, only one profile is given (Fig. 5). The location of the geo-electrical profile is shown in Fig. 6. A three layer model is proposed. Low values on the landslide are recorded to a depth of approximately $20 \mathrm{~m}$. An undulating boundary shows the transition to high resistivity values. The low values correspond to the disintegrating materials of the landslide, which are derived from the Arosa Zone, and mainly from the Raibler Formation (anhydrite and gypsum). The high values are characteristic for in situ bedrock values. The surrounding geomorphology, in which sink holes and collapse dolines are common features, strongly suggests that the undulating boundary is influenced by karst. The higher surface resistivity values near and upslope from point $192 \mathrm{~m}$ coincide with a cover of debris flow material composed of coarse dolomite rock fragments on top of the landslide. These boundaries match the surface distribution of the debris flows as shown in Fig. 3.

In Fig. 6 the total displacements values over 15 years within the landslide indicate that the largest displacements occurred near the frontal section of the landslide. Benchmarks 5 and 11 have a vertical displacement of more than $3 \mathrm{~m}$. This is related to local steeper slope gradients, which favours the development of tension cracks and sliding. This pattern can be attributed to fragmentation of the frontal slide masses into smaller slide units. After failure, these slides are too small to pose a serious threat to Malbun village. Benchmark no. 17 is located on an individual rock fall block that has moved down slope, resulting in a local optimum in the displacement rate.

The hazard zonation map (Fig. 7) shows all areas that are potentially exposed to debris flows. The largest source area for active debris flows is in D1. Debris may travel north along the central landslide through the wooden channels; in a worst case scenario they may cover the debris fan in $\mathrm{A} / \mathrm{B} 2 / 3$.

\section{Conclusions and discussion}

The combination of geomorphological analyses and visualization in GIS of the geo-electrical profiling and the benchmark measurements has resulted in the following observations:

- Debris flows still occur in the Schlucher catchment. Debris flows are still an important natural hazard and can pose a serious risk to Malbun village if no countermeasures are taken.

- The central landslide does not pose a severe risk to Malbun. Surface displacement rates indicate slow movements, and the geomorphological map shows that the landslide is disintegrating into minor slides. Therefore, a major outbreak of material is unlikely, but small failures can be expected.

- Karst is an active process that locally favours slope instability. Locally, collapse dolines can reduce the impact of debris flows, by serving as sediment traps.

Geomorphological information is integrated in hazard zonation studies since Kienholz (1977) used his geomorphological approach in hazard zonation. Our research presents digital thematic maps prepared on the basis of a detailed geomorphological map stored in a GIS. Our study emphasizes on detailed site specific observations, whereas many (semi) quantitative GIS and/or stability models emphasize on geostatistical calculations (Moon et al., 2004; Ercanoglu et al., 2004; Corominas et al., 2004; Santacana et al., 2004). In both cases the results may provide emergency management planners with estimates or approximations of the likely extent of features (Fabbri et al., 2003; Fernandez et al., 2003; Moon et al., 2004). Often this is insufficient because of missing input values or observations. The relation between terrain units is often ignored, in most cases because the total landscape is not mapped, but only the landslides themselves. This may result in under- or overestimating of the landslide susceptibility (Chau et al., 2003). This is particularly true for areas where the boundary conditions, such as the geological structure and lithology, are highly complex and the scale needed for modelling is very detailed. A possible disadvantage is that the reproducibility of the "expert driven" method is not optimal, compared to other methods that implicitly use expert knowledge (e.g. Corominas et al., 2003; Santacana et al., 2003). However, for detailed studies a balance has to be found between workability and suitability of the method.

One advantage of integrating the scanned symbol based geomorphological map into GIS is that it forms a background image and thereby remains a valuable source of information in interpreting geomorphological hazards. For example, the variability of material cover and process intensity, expressed by changing the density of symbols is still recognizable and increases the practical value of the various GIS layers. This means that the source of information upon which the decisions are made is visible to others. A further advantage is that the final maps do not rely only on instability features alone, but are based on a full representation of the landscape. A further strength of GIS is also that both quantitative and qualitative terrain parameters can easily be integrated.

Acknowledgements. We would like to thank J. Zürcher and E. Banzer from the "Landesamt Fur Wald, Natur und Landschaft" in Vaduz, for kindly providing us with the colour infrared air-photos and the displacement data of the Schlucher catchment. Moreover, R. J. Sporry from ITC Delft, D. T. Biewinga and J. Rupke and are kindly acknowledged for their support in the geophysical survey. The students J. Timmers and T. Busnach from the Institute for Biodiversity and Ecosystem Dynamics (IBED) of the University of Amsterdam are thanked for their assistance with the geodetic and geo-electrical measurements. J. van Smaalen of the GIS-studio, 
University of Amsterdam is thanked for his advice in the GIS data handling and visualization.

Edited by: F. Guzzetti

Reviewed by: M. Soldati and another referee

\section{References}

Allemann, F.: Geologische Karte des Fürstentums Liechtenstein, Regierung des Fürstentums Liechtenstein, Vaduz, 1985.

Chau, K. T., Sze, Y. L., Fung, M. K., Wong, W. Y., Fong, E. L., and Chan, L. C. P.: Landslide hazard analysis for Hong Kong using landslide inventory and GIS, Computers \& Geosciences, 30(4), 429-443, 2003.

Corominas, J., Copons, R., Vilaplana, J. M., Altimir, J., and Amiga, $\mathrm{J} .:$ Integrated landslide susceptibility analysis and hazard assessment in the principality of Andorra, Nat. Hazards, 30(3), 421435, 2003.

Dai, F. C., Lee, C. F., and Ngai, Y. Y.: Landslide risk assessment and management: an overview, Engineering geology, 64, 65-87, 2002.

de Graaff, L. W. S., De Jong, M. G. G., Rupke, J., and Verhofstad, J.: A geomorphological mapping system at scale 1:10000 for mountainous areas, Zeitschrift für Geomorphologie N.F., 31, 2, 229-242, 1987.

Dorren, L. K. A.: Mountain Geoecosystems. Gis modelling of rockfall and protection forest structure, PHd Thesis, Universiteit van Amsterdam, 162 pp., 2002.

Ercanoglu, M., Gokceoglu, C., and van Asch, T. W. J.: Landslide susceptibility zoning north of Yenice (nw Turkey) by multivariate statistical techniques, Nat. Hazards, 32(1), 1-23, 2004.

Fabbri, A. G., Chung, C.-J. F., Cendrero, A., and Remondo, J.: Is prediction of landslides posible with a GIS?, Nat. Hazards, 30(3), 487-499, 2003.

Fernandez, T., Irigaray, C., el Hamdouni R., and Chacon, J.: Methodology for landslide susceptibility mapping by means of a GIS: application to the Contraviesa area (Granada, Spain), Nat. Hazards, 30(3), 297-308, 2003.

Garcia-Mélendez, I., Molina, I., Ferre-Julia, M., and Aguirre, J.: Multi-sensor data integration and GIS-analysis for natural hazard mapping in a semiarid area (southeast Spain), Adv. Space Res., 21(3), 493-499, 1998.

Gaspar, J. L., Goulart, C., Queiroz, G., Silveira, D., and Gomez, A.: Dynamic structure and data sets of a GIS database for geological risk analysis in the Azores volcanic islands, Nat. Hazards Earth Syst. Sci., 4, 233-242, 2004.

Guzzetti, F., Carrara, A., Cardinali, M., and Reichenbach, P.: Landslide hazard evaluation: a review on current techniques and their application in a multi-scale study, central Italy, Geomorphology, 31, 181-216, 1999.

Guzzetti, F. and Tonelli, G.: Information system on hydrological and geomorphological catastrophes in Italy (SICI): a tool for managing landslide and flood hazards, Nat. Hazards Earth Syst. Sci., 4, 213-232, 2004.
Helmcke, D.: Geologie der südliche Klostertaler Alpen (Vorarlberg, Österreich), Geologica et Palaeontologica, 8, 131-147, 1974.

Imeson, A. C. and Cammeraat, L. H.: Scaling up from field measurements to large areas using the Desertification Response Unit and Indicator Approaches, in: Rangeland Desertification, edited by: Arnalds, O. and Archer, S., Dordrecht, Kluwer Academic Publishers, 1999.

Iqballudin, Saifuddin, Javed, A., and Moni, M.: Terrain mapping unit based approach for sustainable agricultural development in India - an example from plains ecosystem at semi-arid interface, J. Arid Environ., 42, 319-330, 1999.

Kienholz, H.: Kombinierte geomorphologische Gefahrenkarte 1:10000 von Grindelwald, Geographica Bernesia G4, Geographisches Institut der Universität Bern, 204 pp., 1977.

Kobel, M.: Erläuterungen zur Tektonik des Rätikon, Jahresbericht des Vorarlberger Landesmuseum Vereins, 145-260, 1969.

Meyerink, A. M. J.: Data aquisition and data capture through terrain mapping units, ITC Journal, 23-44, 1988.

Moon, V. and Blackstock, H.: A methodology for assessing landslide hazard using deterministic stability models, Nat. Hazards, 32(1), 11-134, 2004.

Oberhauser, R.: Erläuterungen zur geologisch-tektonischen Übersichtskarte von Vorarlberg 1:200 000, Geologische Bundesanstalt, Wien, 1998.

Rickli, C. and Banzer, E.: Gefahrenkartierung im Fürstentum Liechtenstein, Interpraevent 1996, Tagungspublikation, vol. 3, p. 183-192, 1996.

Ring, U., Ratschbacher, L., and Frisch, W.: Plate-boundary kinematics in the Alps: Motion in the Arosa suture zone, Geology, 16, 696-698, 1988.

Santacana, N., Baeza, B., Corominas, J., de Paz, A., and Marturia, J.: A GIS-based multivariate statistical analysis for shallow landslide susceptibility mapping in La Pobla de Lillet area (Eastern Pyrenees, Spain), Nat. Hazards, 30(3), 281-295, 2003.

Seijmonsbergen, A. C.: Geomorphological evolution of an alpine area and its application to geotechnical and natural hazard appraisal, PHd thesis, University of Amsterdam, 109 pp., 1992.

Soeters, R. and van Westen, C. J.: in: Landslides - investigations and mitigation, edited by: Turner, A. K. and Schuster, R. L., Special report 247 - Transportation Research Board, National Academy Press, Washington D.C., 1996.

Suryana, N.: A geo-information theoretical approach to inductive erosion modeling based on terrain mapping units. $\mathrm{PhD}$ thesis, Landbouwuniversiteit Wageningen, The Netherlands, 234 pp, 1996.

van Westen, C. J., Rengers, N., and Terlien, M.: Prediction of the occurrence of slope instability phenomena through GIS-based hazard zonation, Geologische Rundschau, 86, 404-414, 1997.

Varnes, D. J.: Landslide hazard zonation: a review of principles and practice, Nat. Hazards, 3, UNESCO, 63 pp., 1984.

Wenzel, H.: Schucher - Gefahren und Sanierungsmassnahmen, Sonderdruck aus der Jahresschrift "Bergheimat" des Liechtensteiner Alpen Vereins, 19-34, 1985. 